Hydrol. Earth Syst. Sci., 17, 1533-1545, 2013

www.hydrol-earth-syst-sci.net/17/1533/2013/

doi: $10.5194 /$ hess-17-1533-2013

(c) Author(s) 2013. CC Attribution 3.0 License.

\title{
Desiccation-crack-induced salinization in deep clay sediment
}

\author{
S. Baram ${ }^{1}$, Z. Ronen ${ }^{1}$, D. Kurtzman ${ }^{2}$, C. Külls ${ }^{3}$, and O. Dahan ${ }^{1}$ \\ ${ }^{1}$ Department of Environmental Hydrology \& Microbiology, Zuckerberg Institute for Water Research, Albert Katz \\ International School for Desert Studies, Blaustein Institutes for Desert Research, Ben-Gurion University of the Negev, \\ Sede Boqer Campus, 84990, Israel \\ ${ }^{2}$ Institute of Soil, Water and Environmental Sciences, Agricultural Research Organization, The Volcani Center, \\ Bet Dagan 50250, Israel \\ ${ }^{3}$ Institute for Hydrology, Albert-Ludwigs-University Freiburg, Fahnenbergplatz, 79098 Freiburg, Germany
}

Correspondence to: S. Baram (baramsha@post.bgu.ac.il)

Received: 22 October 2012 - Published in Hydrol. Earth Syst. Sci. Discuss.: 21 November 2012

Revised: 7 March 2013 - Accepted: 28 March 2013 - Published: 22 April 2013

\begin{abstract}
A study on water infiltration and solute transport in a clayey vadose zone underlying a dairy farm waste source was conducted to assess the impact of desiccation cracks on subsurface evaporation and salinization. The study is based on five years of continuous measurements of the temporal variation in the vadose zone water content and on the chemical and isotopic composition of the sediment and pore water in it. The isotopic composition of water stable isotopes $\left(\delta^{18} \mathrm{O}\right.$ and $\left.\delta^{2} \mathrm{H}\right)$ in water and sediment samples, from the area where desiccation crack networks prevail, indicated subsurface evaporation down to $\sim 3.5 \mathrm{~m}$ below land surface, and vertical and lateral preferential transport of water, following erratic preferential infiltration events. Chloride $\left(\mathrm{Cl}^{-}\right)$concentrations in the vadose zone pore water substantially increased with depth, evidence of deep subsurface evaporation and down flushing of concentrated solutions from the evaporation zones during preferential infiltration events. These observations led to development of a desiccation-crack-induced salinization (DCIS) conceptual model. DCIS suggests that thermally driven convective air flow in the desiccation cracks induces evaporation and salinization in relatively deep sections of the subsurface. This conceptual model supports previous conceptual models on vadose zone and groundwater salinization in fractured rock in arid environments and extends its validity to clayey soils in semi-arid environments.
\end{abstract}

\section{Introduction}

Expansive clay soils, which are dominated by $2: 1$ clay minerals, crack during desiccation when substantial matric suction in the pore structure of the fine-grained clays develops and the tensile strength exceeds the cohesive strength of the soil matrix (Mermut et al., 1996; Nahlawi and Kodikara, 2006; Costa et al., 2013). Desiccation cracks can serve as water conduits and preferentially transport water and solutes into deep sections of the vadose zone during the generation of local runoff or occasional flooding (Bronswijk et al., 1995; Kurtzman and Scanlon, 2011; Baram et al., 2012a). Several field-scale and large-scale lysimeter experiments have shown that, even though desiccation cracks may disappear on the land surface under wet conditions, the cracks will not completely disappear from the subsurface and may still serve as preferential flow paths (Mermut et al., 1996; Gerke, 2006; Acworth and Timms, 2009; Greve et al., 2010; Kishne et al., 2010; Baram et al., 2012a). Mermut et al. (1996) stated that while cultivation and wetting of a Vertisol land surface may result in the removal of observed desiccation cracks from the plow zone, the cracks below this zone will continue to exist. Acworth and Timms (2009) showed that groundwater at 16 and $34 \mathrm{~m}$ below a Vertisol field was recharged by irrigation water during a single irrigation season. Baram et al. (2012a) showed rapid (within hours) increases in sediment water content in deep sections ( $>12 \mathrm{~m}$ ) of a clayey vadose zone, following intensive rain events and short duration flooding on the land surface. 
Evaporation of water from sediment profiles has been relatively well studied over the years. Salt buildup and isotopic enrichment of water stable isotopes (deuterium $\left({ }^{2} \mathrm{H}\right.$ ), and oxygen-18 $\left.\left({ }^{18} \mathrm{O}\right)\right)$ in the sediments near the land surface due to evaporation have been observed in many studies, including column experiments and field observations of unsaturated soils (Allison et al., 1983, 1985; Barnes and Allison, 1988; Nativ et al., 1995, 1997; Scanlon et al., 1997; Scanlon and Goldsmith 1997; Gazis and Feng, 2004, and citations within; Kurtzman and Scanlon, 2011). In arid and semi-arid environments, the annual evapotranspiration potentials are higher than the annual precipitation levels (Scanlon et al., 1997). In such environments, the high evapotranspiration potentials minimize the deep percolation and lead to the accumulation of salts in the upper unsaturated zone (Allison et al., 1985; Sharma and Hughes, 1985; Scanlon, 1991). Accordingly, chloride $\left(\mathrm{Cl}^{-}\right)$concentrations have been used to quantify moisture fluxes in the field (Sharma and Hughes, 1985; Scanlon, 1991; Scanlon and Goldsmith, 1997). Kurtzman and Scanlon (2011) compared $\mathrm{Cl}^{-}$concentration profiles taken from the clayey vadose zone beneath both cultivated and uncultivated Vertisol. They observed a significant accumulation of $\mathrm{Cl}^{-}$in the vadose zone under the uncultivated plot. Using flow simulations, they concluded that the matrix infiltration rates under the uncultivated plots were much lower than the ones under the cultivated plots and that the uncultivated plots enabled rapid freshwater recharge through discrete preferential paths. Nativ et al. $(1995,1997)$ studied groundwater recharge under fractured chalk in an arid area. They proposed, based on chemical and isotopic data, that a small portion of the rainwater percolates downward through the matrix, while a larger percentage of the percolating water moves through preferential pathways in fractures. They found that the water flowing through the fractures was typically not exposed to evaporation, and that it penetrated the matrix across the fracture walls, depleting the stable isotopic composition and diluting the salt concentrations across the unsaturated zone.

While fractures in the vadose zone are usually considered as preferential flow paths that serve mainly as water conduits for deep and fast water percolation (Dahan et al., 1999, 2000; Zhou et al., 2006; Ireson et al., 2009), recent studies have shown that they can serve as air conduits that enhance aeration and water evaporation in deep sections of the vadose zone (Nachshon et al., 2008; Kamai et al., 2009; Weisbrod et al., 2009). It has been shown that, in arid environments, the density gradients between the air within a fracture void (light, wet and warm air) and the atmospheric air (cooler, drier and heavier (denser)) trigger air convection within the void, which enhances water evaporation and salt accumulation in the sediment surrounding the fracture walls (Weisbrod and Dragila, 2006; Kamai et al., 2009). It was further suggested that preferential infiltration of water during rain storms flushes down the solutes that have accumulated on the fracture walls and induces groundwater salinization
(Weisbrod et al., 2000; Weisbrod and Dragila, 2006). In the fracture void, the air replacement rate by convection and its consequent water vapor flux potential out of the fracture void were found to be orders of magnitude faster than the water replacement rate by water flow in the sediment matrix surrounding the fracture void. Due to the fast air exchange rate, resulting from nighttime thermal convection, air humidity within the fracture void is likely to be similar to the humidity in the atmospheric air during the night (Nachshon et al., 2008; Weisbrod et al., 2009). During the day, windinduced convection can also result in enhanced fracture voidatmosphere air circulation (Nachshon et al., 2012). The removal of water vapor (as humidity) from the fracture void dries the sediment surrounding crack walls which leads to the development of a capillary gradient and advective pore-water flow from the wetter zones of the sediment matrix toward the drier fracture surfaces. This study aims to assess the hypothesis that a similar phenomenon can occur in clay soils due to the formation of desiccation cracks.

The objective of this study is to asses the impact of desiccation cracks in clay sediment in a semi-arid environment on subsurface evaporation and salinization processes. The study was conducted through a detailed investigation of the interrelations between (a) water infiltration mechanisms, (b) distribution of solute concentration across the vadose zone profile, and (c) stable isotope composition $\left(\delta^{18} \mathrm{O}, \delta^{2} \mathrm{H}\right)$ of water and sediment samples across a clayey vadose zone in the vicinity of a wastewater source. The study was conducted in the framework of a research project on the impact of dairy farms' waste storage ponds on groundwater recharge.

\section{Materials and methods}

\subsection{Study area}

The study area is located in the Beer Tuvia region $\left(40 \mathrm{~km}^{2}\right)$, above the southern part of the Coastal Aquifer in Israel. This phreatic aquifer is composed mainly of sand and calcareous sandstone of the Pleistocene age, and is overlaid by clay that originated from swamps or riverbeds. The thickness of the clay layer can vary from several centimeters to several meters (up to $20 \mathrm{~m}$ ) within a distance of several hundred meters (Issar, 1968). The climate is Mediterranean with a hot $\left(24.3^{\circ} \mathrm{C}\right.$ on average $)$ and dry summer and a cooler $\left(14.2^{\circ} \mathrm{C}\right.$ on average) rainy winter (November to March). The mean annual precipitation is $\sim 450 \mathrm{~mm}$, which falls mostly through 5-8 rainy episodes. The average yearly evaporation potential is $1725 \mathrm{~mm}$ (using a class-A pan; data available at http://www.ims.gov.il/IMSEng/Meteorologika/ evaporation+Tub/monthly+data/). Groundwater is mainly recharged by percolation of seasonal rainwater and agricultural return flow from irrigated fields. Over the past $60 \mathrm{yr}$ the area has been intensively cultivated, and since the 1990s, it has hosted approximately 12500 lactating cows in 140 
dairy farms. Throughout the past five decades, the average $\mathrm{Cl}^{-}$concentration in the groundwater in the Beer Tuvia region has increased from $\sim 200 \mathrm{mg} \mathrm{L}^{-1}$ in the 1930s to $>600 \mathrm{mg} \mathrm{L}^{-1}$ today (Weinberger, 2007).

This research was conducted in a dairy farm representative of the area that has 60 dairy cows and 30 heifers and calves. Discharges of wastewater and liquid manure from the farm (about $7 \mathrm{~m}^{3} \mathrm{~d}^{-1}$ ) are stored on site in a single-stage unlined earthen storage pond $\left(\sim 200 \mathrm{~m}^{2}\right.$ and $1 \mathrm{~m}$ deep) without specific maintenance procedures, such as drainage or solids removal. Overflow from the pond continuously flows into a waste channel ( $\sim 2 \mathrm{~m}$ wide, $1 \mathrm{~m}$ deep and $200 \mathrm{~m}$ long). Both the waste storage pond and the channel are flooded with liquid manure year-round. The dairy farm has operated under very similar conditions from the late 1960s until today.

The stratigraphy underlying the waste pond is clay $(0-6 \mathrm{~m})$ overlaying sandy loam $(6-8 \mathrm{~m})$, and then calcareous sandstone $(>8 \mathrm{~m})$. The stratigraphy underlying the liquid waste channel is clay $(0-12 \mathrm{~m})$ overlaying calcareous sandstone (Fig. 1). The water table at the study site is located at $\sim 47 \mathrm{~m}$ below the surface (b.l.s.). The particle-size distribution of the local top clay is $26 \%$ sand, $22 \%$ silt, and $52 \%$ clay, of which $90 \%$ are illite-smectite minerals (Baram et al., 2012a). Major and minor desiccation cracks (aperture $>1 \mathrm{~mm}$ and $<1 \mathrm{~mm}$, respectively) form a desiccation-crack network that crosses the entire clay layer and remains open and hydraulically active year-round, even under relatively high water content $\left(>0.50 \mathrm{~m}^{3} \mathrm{~m}^{-3}\right)$ (the method in which the major desiccation cracks were surveyed can be found in Baram et al., 2012a) (Fig. 2). The major desiccation cracks create polygons with average dimensions of $1.0 \times 0.7 \mathrm{~m}^{2}$, separated by cracks with an average aperture of $0.055 \pm 0.017 \mathrm{~m}$ and an average depth, in which the aperture of the crack is greater than $0.006 \mathrm{~m}$, of $0.65 \pm 0.19 \mathrm{~m}$.

\subsection{Monitoring, sampling and analysis}

The hydrological processes in the unsaturated zone in the entire waste pond area (center, banks and margins) were studied using three independent vadose-zone monitoring systems (VMSs), as well as sediment sampling, using various drilling techniques (bucket-augers and direct push coring methods). The VMS is designed to collect in situ real-time continuous measurements of the water contents and the temperatures in the vadose zone, using flexible time domain reflectometry probes (FTDRs) and thermocouples, respectively, and to allow frequent sampling of the sediment pore water, using vadose zone sampling ports (VSPs) (Dahan et al., 2007, 2008, 2009; Rimon et al., 2007, 2011). The VSPs are essentially suction lysimeters that have been modified for operation with the VMS in deep sections of the vadose zone. Pore-water sampling from unsaturated sediments is achieved by creating hydraulic continuity between the sediment and the sampling cell using a flexible porous interface (Dahan et al., 2009; Patents \# US 6,956,381; US 12/222,069; EP 07706061.4; IL

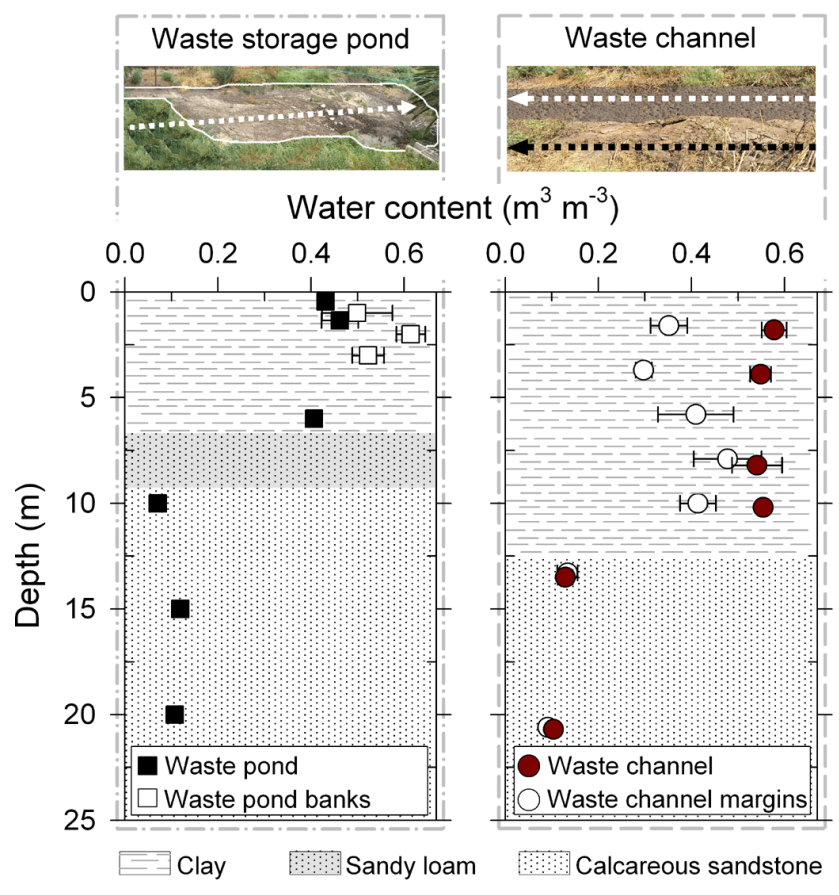

Fig. 1. Water content profiles under the waste channel and its margins and under the waste storage pond and its banks. Results are presented as averages, and the horizontal bars are the standard deviation between all the measurements (2007-2011) made by each FDTR probe.

193126). Detailed descriptions of the VMSs' setup and the monitoring probes used in this study can be found in previous publications by Baram et al. (2012a, b). Generally, one VMS was installed from the pond margins towards its center, and two additional VMSs were installed under the waste channel and its margins (Fig. 3 and Table 1). Pore-water samples, volumetric water content and temperature measurements were taken down to a depth of $30.5 \mathrm{~m}$ below land surface (b.l.s.) under the waste storage pond, to a depth of $3.5 \mathrm{mb}$ b.l.s. under the pond margins and to a depth of $21 \mathrm{mb}$ b.l.s. under both the waste channel and its margins. The infiltrating wastewater was sampled at the interface between the bottom of the waste storage pond and the underlying sediments using conventional suction lysimeters.

The volumetric water content of the sediment in the vadose zone was measured every $60 \mathrm{~min}$ during the dry season (April-October) and every $15 \mathrm{~min}$ during the wet season (November-March). The volumetric water content in the upper clay sediment under the waste storage pond was evaluated once a year using sediment core samples as described in Baram et al. (2012b). The temperature profile along the desiccation crack void and along the sediment profile was measured every 10 and $60 \mathrm{~min}$, respectively. Rainwater was collected in a PVC cylinder $(4 \mathrm{~cm}$ i.d. $\times 30 \mathrm{~cm})$ filled with $2 \mathrm{~cm}$ of liquid paraffin (Floris, Israel), and sampled once a month to represent the average isotopic $\left(\delta^{18} \mathrm{O}, \delta^{2} \mathrm{H}\right)$ values. Water 


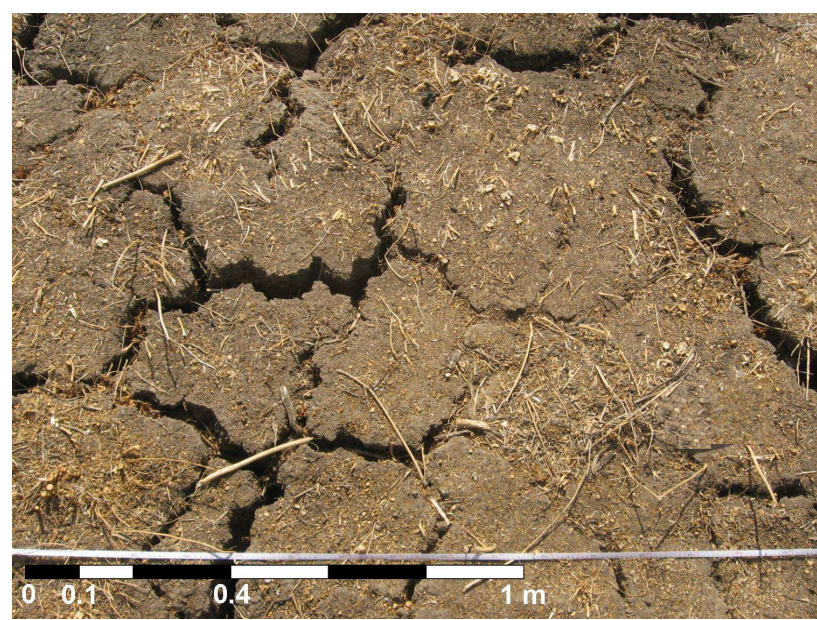

Fig. 2. Desiccation cracks at the study site.

samples from the waste sources (pond and channel) and from the vadose zone were collected every 6 to 12 weeks. Water samples for major ions were stored in polypropylene bottles and kept on ice until they reached the laboratory $(<12 \mathrm{~h})$, where they were filtered ( $45 \mu \mathrm{m}$ glass fiber filter) and kept at $4^{\circ} \mathrm{C}$ until analysis ( $<2$ weeks). Water samples for isotopic analysis were taken between January 2011 and May 2011, and placed in $2 \mathrm{~mL}(12 \times 32 \mathrm{~mm})$ screw-top borosilicate glass vials cupped by closures with silicone septa until analysis (Fisher Scientific, Catalog No. 03-391-8 and No. 03-391-14, respectively).

Sediment sampling for the determination of the isotopic composition of the bulk pore water in the vadose zone was performed using a direct push coring machine (PowerProbe 9700-VTR AMS, American Falls, ID, USA) equipped with a $0.06 \mathrm{~m}$-i.d. dual tube piston sampler (5005.74; AMS) and a single-use 0.035 m-i.d. PVC liner (5006.427; AMS). Sediment core samples were taken from three locations: (a) under an undisturbed plot which is unaffected by the waste sources, representing the background; (b) $3 \mathrm{~m}$ away from the waste source, representing an area that is seldom subjected to flooding by wastewater overflows; and (c) under the center of the waste channel. The core samples were taken at the end of the dry summer (October 2010, following the last precipitation event in March 2010) and at the end of the wet winter (April 2011), in which $0.325 \mathrm{~m}$ of rain had precipitated, and eight days after a $0.03 \mathrm{~m}$ rain event. At each sampling event, cores were taken to a depth of $8-10 \mathrm{mb}$ b.l.s. At the end of the winter, sediment samples were also taken from the upper $0.3 \mathrm{~m}$ of the sediment profile using a garden hand shovel. All cores were immediately dissected into $0.1 \mathrm{~m}$ slices, placed in aluminum-coated bags and sealed to avoid water losses. Due to compaction during direct push coring, the upper sample $(0-1.2 \mathrm{~m})$ was not dissected.

Chloride $\left(\mathrm{Cl}^{-}\right)$concentrations were determined within two weeks after sampling using an ion-chromatograph (Dionex-4500i, USA). Oxygen and hydrogen isotopes

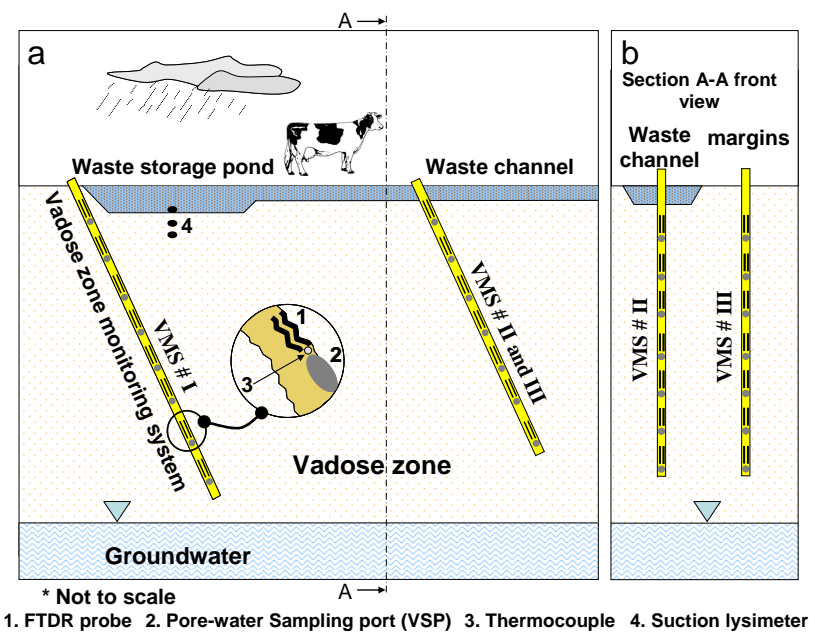

Fig. 3. Schematic side-view illustration of the vadose-zone monitoring system (VMS) installed under the waste storage pond, waste channel and the waste channel margins (a), and front view (A-A) of the VMS installed under the channel and its margins (b) (modified from Baram et al., 2012a).

$\left(\delta^{18} \mathrm{O}-\mathrm{H}_{2} \mathrm{O}, \delta^{2} \mathrm{H}-\mathrm{H}_{2} \mathrm{O}\right)$ in the rain, wastewater, pore water and sediment samples were measured in the laboratory of the Albert Ludwigs University of Freiburg, by the $\mathrm{H}_{2} \mathrm{O}_{\text {(liquid)- }}$ $\mathrm{H}_{2} \mathrm{O}_{\text {(vapor) }}$ equilibration and the tunable laser-spectrometry methodology (detailed description of the method can be found in Garvelmann et al., 2012). A two-point calibration for the $\delta^{18} \mathrm{O}$ and $\delta^{2} \mathrm{H}$ values in the samples was preformed with standards in clay matrix from the same site, in loam and in sand. The overall analytical error, including uncertainties from the sampling, transport and sample preparation during equilibration, is $0.5 \%$ for $\delta^{18} \mathrm{O}$ and $2.5 \%$ or $\delta^{2} \mathrm{H}$.

To evaluate the potential for thermally triggered air convection within the desiccation cracks, the air temperatures within the voids of three neighboring desiccation cracks were measured using thermocouples (copper-constantan thermocouples; PP-T-24 Omega, Stamford, CT, USA), similar to the ones installed on the VMSs. The thermocouples were installed in the desiccation crack voids from the land surface to a depth of $0.7 \mathrm{mb}$ b.l.s. in $0.1 \mathrm{~m}$ intervals. All the monitoring sensors (thermocouples and FTDRs) were operated with Campbell Scientific (Logan, UT, USA) data acquisition and logging instruments, including a CR10X data-logger, TDR100 and AM16/32 and SDM50 multiplexers.

Potential evaporation due to thermally driven air convection in the desiccation cracks was calculated on the basis of a theory that was previously developed by Weisbrod and Dragila (2006) and Nachshon et al. (2008). In general, the calculations simplify the complex natural systems and assume that evaporation occurs from the desiccation cracks' walls and the land surface. As such, the theory simplifies the natural system and does not take into account a reduction in velocity due to thermal diffusion, the effect of fracture aperture variability, the fracture surface texture or limiting factors 
Table 1. The monitoring setup (modified from Baram et al., 2012a).

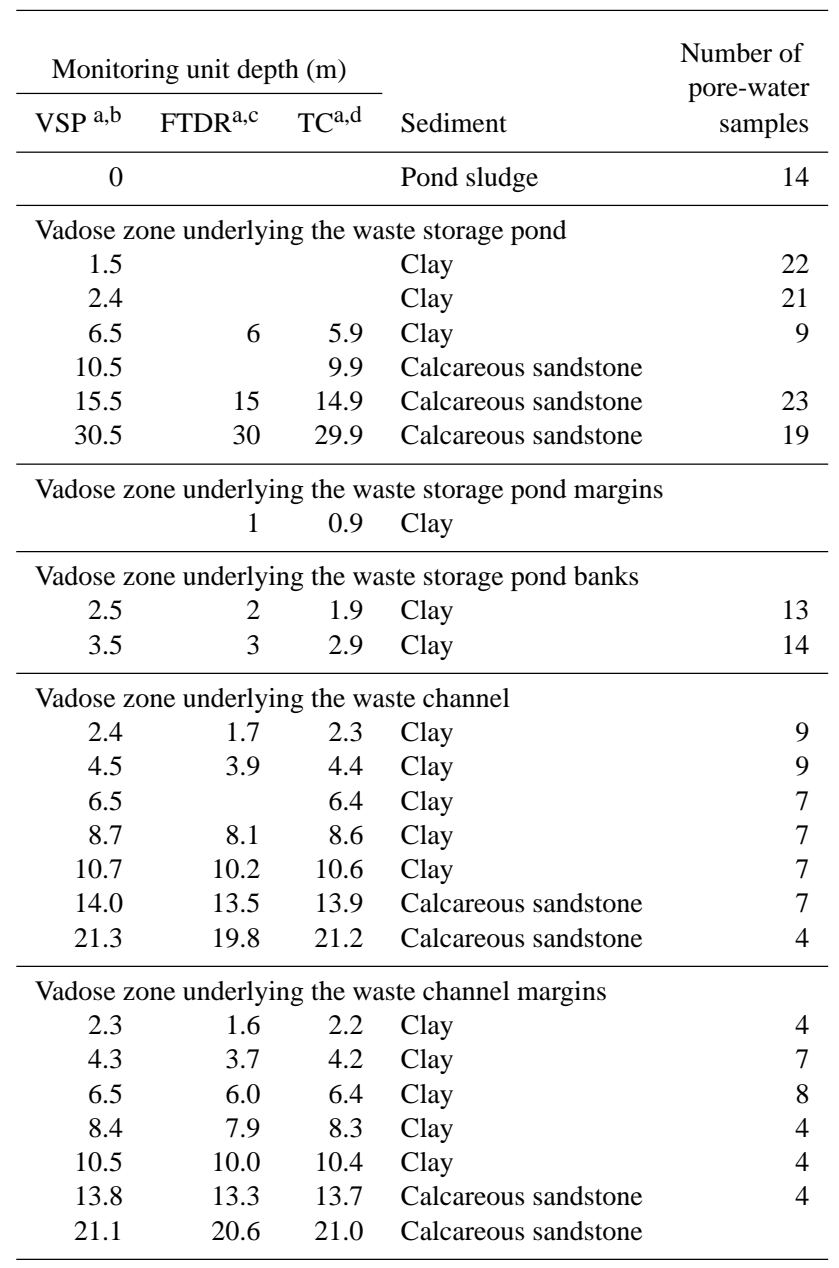

${ }^{a}$ Depth measured relative to the land surface at each site; ${ }^{b}$ vadose zone pore-water sampling port; ${ }^{\mathrm{c}}$ flexible time domain reflectometry probe; ${ }^{\mathrm{d}}$ thermocouple.

such as the transport of the pore water from the sediment matrix to the crack walls. We assumed that the atmospheric air becomes water saturated (relative humidity of $100 \%$ ) immediately as it enters the crack void, and that once convection is initiated, the entry of cool dry fingers of atmospheric air and the venting of the crack will continue until atmospheric warming would reverse the thermal gradient in the crack (typically right after sunrise; Weisbrod et al., 2009). Detailed descriptions of the equations we used can be found in the supporting information. It should be clarified that actual water vapor loss, due to convection, depends on the water vapor pressure differences between the atmospheric and the fracture air. As the thermal gradient increases and, subsequently, convective fluxes, the limiting factor becomes the ability of the matrix to provide water vapor to the fracture air (Kamai et al., 2009; Weisbrod et al., 2009). Kamai et al. (2009) showed that at a temperature difference (delta $T$ ) of $10^{\circ} \mathrm{C}$, the water vapor loss due to thermal convection is at a maximum, and increasing delta $T$ will not result in increased water vapor loss.

\section{Results and discussion}

For the convenience of readers and proper interpretation of the results described here, a brief description of the main findings from previous stages of this study are presented here. Baram et al. (2012a) showed that water percolation through the clay sediments in the vicinity of a waste source is controlled by two main processes: (a) continuous slow infiltration from the bottom of the waste source through the clay matrix (flux rate of a few millimeters per day), and (b) fast percolation of rain and wastewater through desiccation cracks in velocities exceeding several meters per hour, to a depth exceeding $10 \mathrm{~m}$. Following these hydrological findings and observations on the bio-chemical characteristics of the subsurface (Baram et al., 2012b; Sher et al., 2012), the subsurface around the waste source was divided into three main zones: (a) the center of the permanently flooded waste pond (away from the banks). This area is subjected mainly to slow water percolation from the pond bottom. In this zone, sediment water content is relatively constant and low, reaching only $\sim 0.40 \mathrm{~m}^{3} \mathrm{~m}^{-3}$ (70\% saturation) (Fig. 1 waste pond). (b) The waste source banks. This area is located under the edges of the waste source where the dominant flow mechanism is controlled by preferential flow through desiccation cracks. In this respect, the waste channel is considered as two neighboring waste source banks. The vadose zone in this region is subjected to frequent infiltration events of wastewater due to fluctuations in the wastewater level, as well as to rainwater infiltration during the winter time. The clay sediment profile underlying the waste source banks was found to be consistently wetter than all the other regions of the pond, reaching $\sim 0.55 \mathrm{~m}^{3} \mathrm{~m}^{-3}$ (90\% saturation) (Fig. 1 waste pond banks and waste channel). (c) The waste pond margins. This area is located several meters away from the waste source. It is subjected mainly to rainwater, but also to occasional occurrences of flooding by wastewater. Infiltration in this area is predominantly controlled by preferential flow via desiccation crack networks, and the sediment water content in this area is relatively low, reaching only $\sim 0.30 \mathrm{~m}^{3} \mathrm{~m}^{-3}$ ( $45 \%$ saturation) (Fig. 1 waste channel margins).

\subsection{Stable isotope composition}

\subsubsection{Vadose zone under the background area}

Profiles of water stable isotopes $\left(\delta^{18} \mathrm{O}\right.$ and $\left.\delta^{2} \mathrm{H}\right)$ in sediment samples from the background site (an area that is not influenced by wastewater) during the end of the dry summer exhibited uniform values, from near land surface to a depth of $8 \mathrm{~m}$ b.l.s. $\left(\delta^{18} \mathrm{O}-2\right.$ and $\delta^{2} \mathrm{H}-5 \%$ ) (Fig. 4a and b). The $\delta$ values of this profile are significantly enriched compared to the rainwater values $\left(\delta^{18} \mathrm{O}-4.6 \pm 0.7\right.$ and $\delta^{2} \mathrm{H}$ $-19.1 \pm 4.8 \%, n=7$, each-representing an average value for the $0.225 \mathrm{~m}$ of rain sampled, out of the $0.325 \mathrm{~m}$ of precipitation during the 2010-2011 winter). Such enrichment in the 
$\delta$-values suggests that the infiltrating rainwater is subjected to evaporation from the soil profile (Allison et al., 1983). Towards the end of the wet winter, the isotopic profile showed a clear trend of shifting from depleted rainwater values, near the land surface, to enriched/evaporated values at a depth of $\sim 3.5 \mathrm{~m}$ b.1.s. $\left(\delta^{18} \mathrm{O}-1.2 \%\right.$ and $\delta^{2} \mathrm{H}-5.7 \%$ ) (Fig. $4 \mathrm{a}$ and b). This trend of near-surface depletion implies that a significant amount of rainwater percolated to the upper layers of the unsaturated zone $(<1 \mathrm{~m})$ during the wet winter. Below $3.5 \mathrm{~m}$, the $\delta^{18} \mathrm{O}$ and $\delta^{2} \mathrm{H}$ values fluctuated between -1.7 and $-2.9 \%$ and between -5.1 to $-7.2 \%$, respectively. These fluctuations in the $\delta$-values, at the deeper parts of the sediment profile, suggest subsurface mixture between depleted rainwater that percolated deep into the vadose zone via a preferential flow path and the ambient enriched/evaporated water (Nativ et al., 1995, 1997). The assumption that the fluctuations in the $\delta$-values resulted from deep water infiltration through a preferential flow path is supported by the study of Baram et al. (2012a), which demonstrated that a naturally formed desiccation crack network in the clay serves as deep (>12 m) preferential flow paths for rainwater infiltration. Fluctuations in the isotopic profile during the winter, which then evened out during the summer, could have resulted from both slow water redistribution into the matrix (smoothing effect) of the preferentially propagating rainwater, and deep ( $>3 \mathrm{~m}$ ) subsurface evaporation (enrichment). These differences between the summer and winter profiles at the background site differ from the normally observed sawtooth pattern of evaporated (enriched) summer values and unevaporated (depleted) winter values along the vadose zone (DePaolo et al., 2004). Unlike in a sawtooth pattern where the differences in the $\delta$-values can be used to estimate yearly recharge (Garvelmann et al., 2012), here the isotopic profile from the end of the winter represents mixing between the ambient enriched water (from the end of the summer) and the fresh depleted rainwater that preferentially propagates through the desiccation cracks into deeper parts of the vadose zone.

Presenting the relation between $\delta^{2} \mathrm{H}$ and $\delta^{18} \mathrm{O}$ (in a $\delta^{2} \mathrm{H}-$ $\delta^{18} \mathrm{O}$ plane) of all the sediment samples from the background site, during the winter and summer, indicates a clear shift from the average rainwater values on the local meteoric water line (slope of 7.06) to subsurface values on the vadose zone water line (slope of 4.45) (Fig. 5). While the samples from the winter demonstrate a shift with depth from the meteoric water line towards enriched and evaporated values, which are located further below the meteoric water line (winter values depths of 0 to $3 \mathrm{~m}$ vs. depths $>3 \mathrm{~m}$, Fig. 5), the entire summer profile presents enriched and evaporated values compared to both the rain and the meteoric water line (summer values, Fig. 5). Such an isotopic shift from the rain values and the meteoric water line is indicative of subsurface evaporation. The slope of the vadose zone water line indicates that the evaporation occurs at relatively high humidity $(70 \%)$ (Allison et al., 1983; Barnes and Allison, 1983; Sharma and

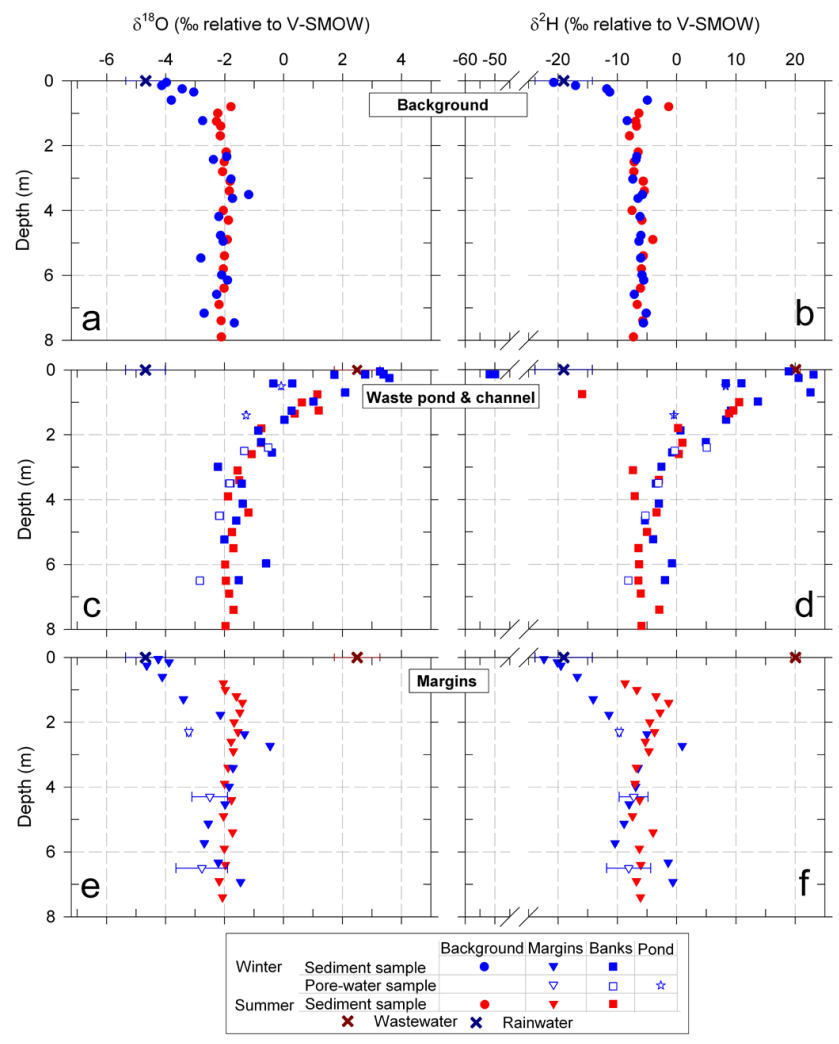

Fig. 4. $\delta^{18} \mathrm{O}$ and $\delta^{2} \mathrm{H}$ in rainwater, wastewater, pore water and in undisturbed sediment samples from the vadose zone underlying the undisturbed background site $(\mathbf{a}, \mathbf{b})$, permanently flooded waste pond and channel $(\mathbf{c}, \mathbf{d})$ and waste source margins $(\mathbf{e}, \mathbf{f})$. The top sample represents an average value for the $0-1.2 \mathrm{~m}$ depth, section. Values for the depths of $0-0.3 \mathrm{~m}$ were obtained only at the end of the winter, from sediment samples taken by a garden hand shovel.

Hughes, 1985; Fontes et al., 1986; DePaolo et al., 2004), which fits the relative humidity during the nighttime at the study site (http://www.ims.gov.il/IMSEng/CLIMATE). The vadose zone water line also indicates that the evaporation was not limited by the diffusive movement of water and vapor through a dry soil layer, since in such cases, the slope is normally smaller than 3.5-3.2 (Allison et al., 1983).

\subsubsection{Vadose zone under the waste pond area}

The water stable isotope composition in sediment samples and in pore water collected from the vadose zone under the waste source area (waste pond and channel) exhibited a trend of gradual depletion with depth, from the wastewater values near the land surface $\left(\delta^{18} \mathrm{O} 2.5 \pm 0.8 \%\right.$ and $\delta^{2} \mathrm{H}$ $20.1 \pm 2.7 \%$ o, $n=3$, each) to depleted values $\left(\delta^{18} \mathrm{O} \sim-2 \%\right.$ o and $\delta^{2} \mathrm{H} \sim-5 \%$ ) at depths of $3.5 \mathrm{~m}$ and deeper (Fig. $4 \mathrm{c}$ and $\mathrm{d}$ ). Unlike isotopic enrichment that may be attributed to evaporation, isotopic depletion of a water source is usually attributed to mixture with a more depleted water source (Nativ et al., 1995, 1997). Accordingly, the observed trend 


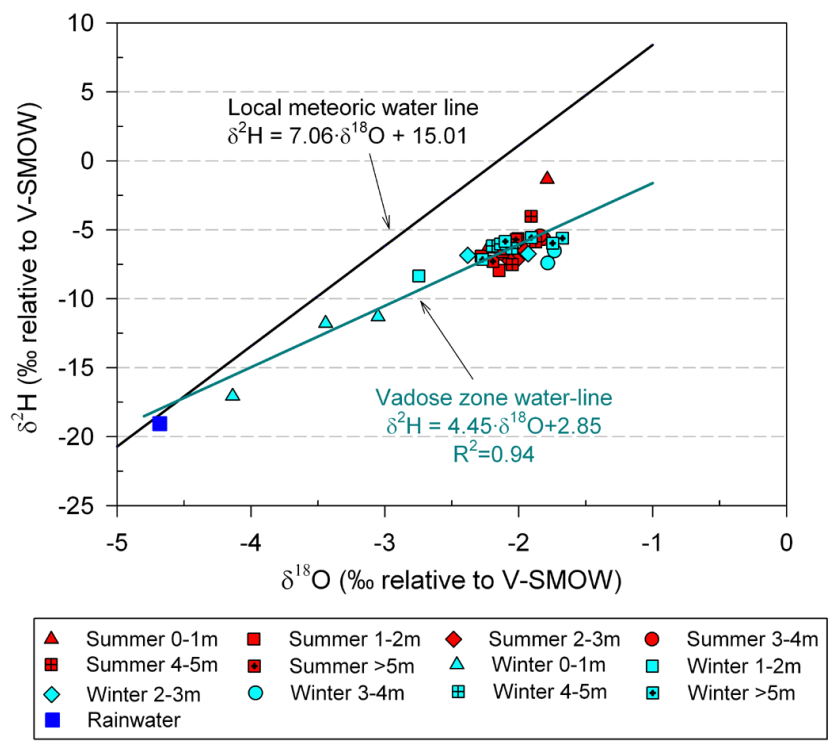

Fig. 5. $\delta^{18} \mathrm{O}$ vs. $\delta^{2} \mathrm{H}$ in rainwater and sediment samples from the vadose zone under the background site. Local meteoric water line is based on the data presented in the work of Asaf et al. (2004).

of depletion with depth under the waste source represents a mixing process between the two water sources that infiltrate into the vadose zone in the area: (a) wastewater, which slowly infiltrates from the permanently flooded waste source's bed, characterized by enriched (heavier) isotopic composition (Fig. 4c and d); and (b) rainwater, which infiltrates down the desiccation cracks from the banks and margins of the waste source, characterized by depleted (lighter) isotopic composition (see Sect. 3.1.1 background) (Fig. 4a and $\mathrm{b})$. The $\delta$-values and the trend of the profile from the margins of the waste source resemble those obtained from the background (Fig. 4e and f vs. Fig. 4a and b), implying that the dominant infiltration and evaporation processes occurring at the margins are similar to those observed at the background. Nevertheless, closer examination of the profiles from the margins reveals higher fluctuations for both enriched and depleted values, suggesting some influence of occasional preferential wastewater infiltrations during pond overflows (Baram et al., 2012b). An outlier, of highly depleted $\delta^{2} \mathrm{H}$ values, was observed between 0.1 to $0.4 \mathrm{~m}$ under the pond (Fig. $4 \mathrm{~d}$ ). Such highly depleted values may have resulted from the presence of isotopically different molecules (such as hydrogen sulfide $\left(\mathrm{H}_{2} \mathrm{~S}\right)$, methane $\left(\mathrm{CH}_{4}\right)$ and hydrogen gas $\left(\mathrm{H}_{2}\right)$ ), which were detected in the sediment samples (unpublished lab measurements using gas analyzer), and are known byproducts of the microbial anaerobic respiration of proteins found in the manure (Gerardi, 2003). Accordingly, theses values were not taken into account in the observed trends and ratios. We suggest that the trend of depletion with depth (Fig. 4c, d) is an outcome of subsurface mixing between preferential infiltrations of depleted rainwater, through the desiccation cracks formed at the banks and margins of the pond, and the enriched wastewater that percolates through the matrix. This assumption is supported by Baram et al. (2012a), which demonstrated the dominance of deep preferential rainwater infiltration through desiccation crack networks. Nativ et al. $(1995,1997)$ proposed a similar mechanism to explain subsurface depletion of enriched (surface-evaporated) matrix water with depleted rainwater that preferentially infiltrated through rock (chalk) fractures. In this study, the subsurface mixing process seems to be significant down to $\sim 3 \mathrm{~m}$ b.l.s. (Fig. $4 \mathrm{c}, \mathrm{d}$ ); below that depth, the $\delta$-values reach a steady state and resemble the ones at the margins and background (Fig. 4). Other mechanisms, such as subsurface mixing between enriched infiltrating water and the capillary rise of depleted shallow groundwater or near/on-surface evaporation of a subsurface-depleted water source, may lead to a similar trend of gradual depletion in $\delta$-values with depth. Yet, these mechanisms are considered irrelevant for this site where the water table is located at $47 \mathrm{~m}$ b.l.s. and the land surface is permanently covered by wastewater.

An additional example of preferential infiltration of rainwater into deep sections of the vadose zone can be seen in Fig. $4 \mathrm{c}$ and e, where the $\delta^{18} \mathrm{O}$ values of pore-water samples (collected by the VMS) from the margins and from the deep profile under the banks ( 4.3 and $6.3 \mathrm{mb}$ b.l.s.) are more depleted and closer to the rainwater values. One should note that the VSPs at the margins yielded pore-water samples mainly following intense rain events, which led to deep rainwater infiltration and increased the water content of the clay sediment $\left(>0.35 \mathrm{~m}^{3} \mathrm{~m}^{-3}\right)$ (Baram et al., 2012a). This relationship between the ability to sample pore water from the relatively dry clay sediments and the deep infiltration of rainwater, along with the observation made by Landon et al. (1999) on the higher proportion of more mobile water (15-95\%) in suction lysimeter samples compared with samples from sediment cores (5-80\%) at the same depth, can explain the consistently lighter composition of the "mobile" pore-water samples compared to the clay matrix water samples. These differences, along with the depleted $\delta^{18} \mathrm{O}$ values observed in sediment of the vadose zone $(5.5$ and $7.2 \mathrm{~m}$ under the background plot and 5-6 $\mathrm{m}$ under the pond margins, Fig. 4a and e, respectively), demonstrate a substantial deep $(>7 \mathrm{~m})$ recharge of rainwater during the wet winter and a redistribution into the drier matrix (summer values, Fig. $4 a, b$, e and f).

\subsection{Soluble salt accumulation in the vadose zone}

Chloride concentration profiles in sediment pore water (collected using the VMS) under all sites surrounding the waste source exhibited a dramatic increase with depth (Fig. 6). The concentrations ranged from $\sim 1600 \mathrm{mg} \mathrm{L}^{-1}$ in the infiltrating wastewater to a very high concentration reaching $11500 \mathrm{mg} \mathrm{L}^{-1}$ at a depth of $6.4 \mathrm{~m}$ under the channel margins. 


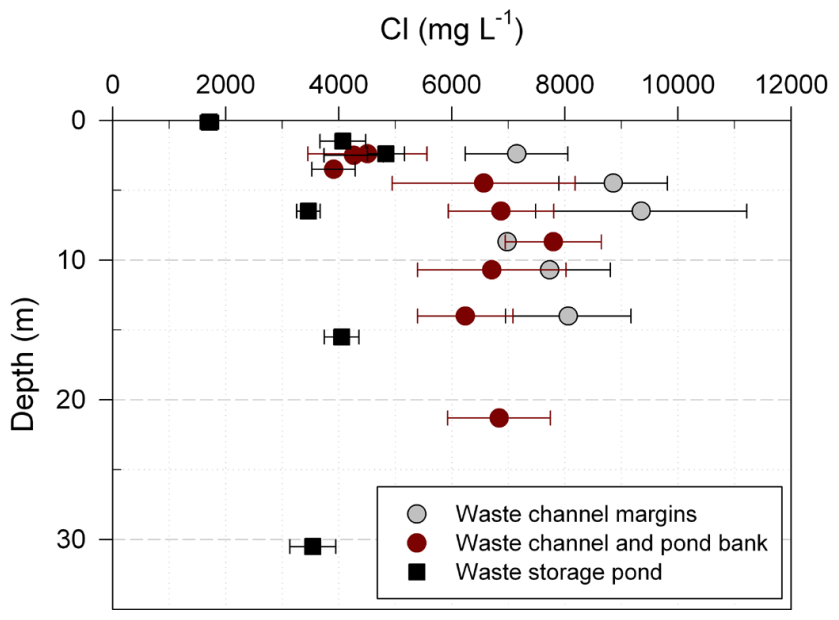

Fig. 6. Vertical distribution of $\mathrm{Cl}^{-}$concentrations in pore water from the vadose zone beneath the waste channel margins, the waste channel and storage pond banks, and the storage pond. Results are presented as averages, and the horizontal bars are the standard deviation between all the water samples collected by each VSP (Table 1).

Under the waste pond, a relatively large surface area that is permanently covered by wastewater, the $\mathrm{Cl}^{-}$concentration increased in the clay profile to $\sim 4000 \mathrm{mg} \mathrm{L}^{-1}$, which then maintained a relatively constant concentration up to the water table at $47 \mathrm{~m}$ b.l.s. (Fig. 6). Further, under the pond banks and under the channel (an area that is considered as two proximate banks), the $\mathrm{Cl}^{-}$concentration increased down through the clay profile up to $\sim 8000 \mathrm{mg} \mathrm{L}^{-1}$ at a depth of $9 \mathrm{~m}$. The most substantial increase in chloride concentration occurred within the upper $7 \mathrm{~m}$ of the clayey vadose zone at the channel margins, where the concentration was 5.5 fold higher than the concentration in the infiltrating wastewater (Fig. 6). In this study, the increase in $\mathrm{Cl}^{-}$concentration, with respect to the known water source (wastewater), could not be attributed to the dissolution of soluble salts from the vadose zone, due to their low concentrations in the natural undisturbed sediment in the area. A similar trend of increasing salinization with depth was observed to depths of 1 to $4 \mathrm{~m}$ in natural environments composed of different sediment types, such as calcrete plains, sands, and sandy to sandy loam mallee (Eucalyptus spp.) woodland (Allison et al., 1985; Cook et al., 1989; Scanlon et al., 2007), silty to gravelly loam shrub land (Scanlon, 1991), and in natural uncultivated cracking clays (Radford et al., 2009). In all cases, the $\mathrm{Cl}^{-}$buildup along the profile reflected the enrichment of atmospherically derived $\mathrm{Cl}^{-}$due to evaporation and root water uptake (transpiration) by the natural vegetation, which resulted in minimal downward matrix flux (several $\mathrm{mm} \mathrm{yr}^{-1}$ ) and a long passage time in the vadose zone. In these studies, the $\mathrm{Cl}^{-}$concentrations increased monotonically throughout the root zone, until reaching a peak at the maximal depth reached by the roots of the natural vegetation. Beneath the bottom of the root zone, the chloride concentrations remained unchanged, indicating piston flow of a single water source under steady state conditions (Gardner, 1967). However, in the work of Kurtzman and Scanlon (2011) and in this work, increasing salinization was observed to a depth of $>4 \mathrm{~m}$, while significant root water uptake by the natural annual shallow-rooted vegetation (maximum $1 \mathrm{~m}$ below the surface, mainly: Malva sylvestris and Malva nicaeensis) could only account for increasing salinization down to $1 \mathrm{~m}$. To overcome this problem, Kurtzman and Scanlon (2011) attributed water loss below $1 \mathrm{~m}$ to deep subsurface evaporation (simulated with the root-water-uptake sink term in the Richards equation using the Hydrus1D code). However, they did not provide a mechanism that can explain such deep evaporation or isotopic values to support this assumption. The $\mathrm{Cl}^{-}$profiles (Fig. 6), along with the isotopic composition (Fig. 4) and the slope of the vadose zone water line (Fig. 5), indicate deep subsurface evaporation, especially since root water uptake does not affect the isotopic ratio of the infiltrating water (Allison et al., 1983; Dawson and Ehleringer, 1991; Thorburn et al., 1993).

\subsection{Subsurface evaporation and salinization of clay sediments}

Temperature measurements in the desiccation crack void to a depth of $0.6 \mathrm{~m}$ at the site indicated daily oscillations of the thermal gradient between the land surface and the subsurface (Fig. 7). The thermal gradient was created by the daily temperature fluctuations. The air inside the deeper sections of the cracks is warmer than the air at the land surface $\left(\Delta>5^{\circ} \mathrm{C}\right)$ during the nighttime (6 p.m. to $6 \mathrm{a} . \mathrm{m}$. LT), and the gradient reverses during the daytime ( 6 a.m. to $6 \mathrm{p} . \mathrm{m}$. LT). Measurements of the temperature along the sediment profile (matrix) from the land surface down to $6 \mathrm{mb}$ b.l.s. (using the thermocouples on the VMSs; Table 1) showed very small daily oscillations and clear seasonal trends (unpublished field observations). The differences between the temperature of the atmospheric air and the temperature of the matrix (down to $6 \mathrm{~m}$ b.l.s. $)$ were most significant during the winter $\left(>10^{\circ} \mathrm{C}\right.$, extending down to $6 \mathrm{~m}$ b.l.s.) and were smaller, but still significant, during the summer (July-September) $\left(>2{ }^{\circ} \mathrm{C}\right.$, extending down to $1.5-2.5 \mathrm{~m}$ b.l.s.). Weisbrod et al. (2000), Weisbrod and Dragila (2006) and Kamai et al. (2009) demonstrated evaporation and salt buildup in fractured rocks, due to thermally driven convective air flow in fracture voids. More research is needed to quantitatively link between the thermal gradient in the field and the depth and magnitude of the thermal convection. Baram et al. (2012a, b) showed that the desiccation crack network in the clay sediment at the vicinity of the waste source is hydraulically active and open yearround. Accordingly, the daily oscillation in the thermal gradient across the desiccation network may well promote subsurface evaporation processes deep into the vadose zone. It is possible that the higher variability in the oxygen signature near the end of the winter, compared to the signature at 


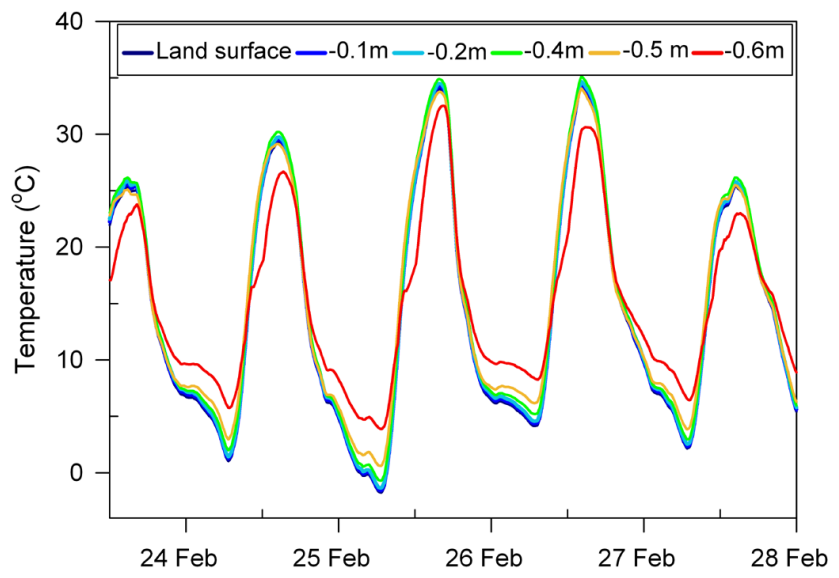

Fig. 7. Daily fluctuations in the temperature profile inside desiccation cracks at the study site. Each line represents a different temperature sensor and its depth, relative to the land surface. Note the unstable conditions (cold air above warm air) that develop in the cracks every night.

the end of the summer (Fig. 4a, c and e), also reflects deeper evaporation during the winter, when the thermal gradients are steeper and deeper. Such processes are more significant at the pond margins where the desiccation crack networks are fully developed and the wet sediment under the pond or channel provides a continuous source of moisture for evaporation. The continuous exposure of the clay sediment at the subsurface to evaporation explains the observed gradual increase in $\mathrm{Cl}^{-}$concentration and the enrichment in the isotopic signature of $\delta^{18} \mathrm{O}$ and $\delta^{2} \mathrm{H}$ with depth. Moreover, subsurface evaporation provides an explanation as to why the slope of the vadose zone water line is not indicative for diffusive evaporation.

A comparison between the $\mathrm{Cl}^{-}$concentrations under the margins $\left(\sim 10000 \mathrm{mg} \mathrm{L}^{-1}\right.$; Fig. 6$)$ and the $\mathrm{Cl}^{-}$concentrations under natural undisturbed clays in the near region (4000-5500 $\mathrm{mg} \mathrm{L}^{-1}$, Kurtzman and Scanlon, 2011) showed that the concentrations under the pond banks and margins are up to twofold higher. We suggest that these differences reflect the difference in both the $\mathrm{Cl}^{-}$concentration of the infiltrating water source (i.e., rainwater $\left(\sim 20 \mathrm{mg} \mathrm{L}^{-1}\right.$; Asaf et al., 2004) vs. wastewater $\left.\left(\sim 1600 \mathrm{mg} \mathrm{L}^{-1}\right)\right)$ and the differences in the water supply to the sediment-air interfaces along the major desiccation crack voids. Under natural conditions, throughout most of the year, the unsaturated clay matrix is relatively dry (Kurtzman and Scanlon, 2011; Baram et al., 2012a), and only a small capillary gradient may exist between the "dry" sediment matrix away from the cracks (i.e., in the center of the polygon) and the drier sediment near the walls of the cracks. Accordingly, only a limited amount of water can flow towards the sediment-air interfaces, along the major desiccation crack voids where evaporation occurs. Increases in the sediment water content of the clay matrix in the polygon (away from the cracks), following the redistribution of deep preferential infiltration of rainwater and wastewater (Baram et al., 2012a), enhance the capillary gradient between the sediment in the polygon and the drier sediment near the walls of the cracks, and enable substantial water loss and salt accumulation due to thermally driven air convection (evaporation). On the other hand, under the pond banks, there is a continuous supply of saltier water (wastewater) from the wet sediment to the drier sediment near the desiccation crack surfaces (mainly at the margins). This continuous water supply prevents the drying of the sediment and the transition to diffusive evaporation through a dry soil layer, maintains the potential for convective evaporation in the cracks, and allows substantial accumulation of salts in the deep vadose zone.

Water infiltration through preferential flow paths created by the desiccation cracks during intensive rain or flooding events transports and redistributes salt that has been accumulated in the fractured clay during the evaporative phases deep into the subsurface. Dissolved salts may be transported by the percolating water, both vertically and laterally, following the cracks' orientation and the governing flow mechanism. While preferential flow along the crack walls may dissolve and flush down salts directly into the deep vadose zone, redistribution of the infiltrating water into the clay matrix may flush down salts from the matrix surrounding the cracks to the deeper sections of the vadose zone, via a gravitydriven, piston-like matrix flow. Solute redistribution in the vadose zone due to vertical and lateral preferential transport of fresher water has been previously reported in fractured rocks (Nativ et al., 1995; Weisbrod et al., 2000) and in soils (Allison et al., 1985; Cook et al., 1989; DePaolo et al., 2004). Accordingly, the increases in salinity with the depth of the sediments underlying the waste pond (from $\sim 1600$ to $\sim 4000 \mathrm{mg} \mathrm{L}^{-1}$ ), the pond banks and waste channel (from $\sim 1600$ to $\sim 8000 \mathrm{mg} \mathrm{L}^{-1}$ ), and the channel margins (from $\sim 1600$ to $\sim 9000 \mathrm{mg} \mathrm{L}^{-1}$ ) (Fig. 6) can be attributed to the lateral transport of saline solution from the evaporative zones at the margins to the less evaporative zones underlying the permanently flooded regions. Evidence for the existence of active desiccation crack networks under the permanently flooded pond and channel at this site were previously reported by Baram et al. (2012a, b) and Sher et al. (2012).

\subsection{Evaporation and deep drainage fluxes}

The annual water loss from the clayey subsurface under the channel and at its banks due to evaporation was estimated using chloride mass balance equations. Accordingly, we assumed that the flow and transport processes in the subsurface are in a steady state: $J_{\text {rain }}+J_{\text {waste }}=J_{\mathrm{ev}}+J_{\mathrm{dr}}$ and $J_{\text {rain }} C_{\text {rain }}+J_{\text {waste }} C_{\text {waste }}=J_{\mathrm{dr}} C_{\mathrm{dr}}$, where $J_{\text {waste }}$ and $C_{\text {waste }}$ are the yearly wastewater infiltration flux through the channel bed $\left(0.875 \mathrm{~m} \mathrm{yr}^{-1}\right.$, Baram et al., 2012b) and the $\mathrm{Cl}^{-}$ concentration in the infiltrating wastewater $\left(1600 \mathrm{mg} \mathrm{L}^{-1}\right.$ (Fig. 6), respectively; $J_{\text {rain }}$ and $C_{\text {rain }}$ are the average yearly precipitation $\left(0.45 \mathrm{~m} \mathrm{yr}^{-1}\right.$; assuming no runoff) and the $\mathrm{Cl}^{-}$ 
concentration in the rainwater (20 $\mathrm{mg} \mathrm{L}^{-1}$, Asaf et al., 2004), respectively; $J_{\mathrm{ev}}$ is the yearly evaporation flux from the clay layer; and $J_{\mathrm{dr}}$ and $C_{\mathrm{dr}}$ are the yearly water flux from the base of the clay layer to the underlying calcareous sand formation. $\mathrm{Cl}^{-}$concentration in the draining water was measured as $\sim 8000 \mathrm{mg} \mathrm{L}^{-1}$; Fig. 6). Based on these assumptions, the yearly evaporation flux from the clay sediment under the channel was found to be $1.1 \mathrm{~m} \mathrm{yr}^{-1}$, indicating that $85 \%$ of the infiltrating water is lost yearly from the clayey vadose zone due to subsurface evaporation (root water uptake is considered negligible in the vicinity of the waste source). Simultaneously, the annual drainage flux from the clay layer to the underlying calcareous sand formation $\left(J_{\mathrm{dr}}\right)$ was found to be $0.20 \mathrm{~m} \mathrm{yr}^{-1}$. The calculated fluxes were validated using the HYDRUS 1-D version 3 computer program (Simunek et al., 1998). We performed forward modeling of over $40 \mathrm{yr}$ of continuous infiltration of water to a $30 \mathrm{~m}$ deep vadose zone composed of homogeneous sandstone layer (using the values for sand predicted by the Rosetta lite, v 1.1 embedded in HYDRUS). A range of constant infiltration fluxes of wastewater were applied at the top boundary $\left(0.05-0.50 \mathrm{~m} \mathrm{yr}^{-1}\right)$ while the lower boundary was the water table with zero pressure. In the simulations, the water content distribution in the sandy vadose zone ranged from 0.075 to $0.12 \mathrm{~m}^{3} \mathrm{~m}^{-3}$ (high water contents were in agreement with high infiltration fluxes). The simulations indicated that under an infiltration flux of $0.2 \mathrm{~m} \mathrm{yr}^{-1}$, the water content in the sandy vadose zone profile resembled the field observations in the upper part of the sand layer $\left(0.097 \mathrm{~m}^{3} \mathrm{~m}^{-3}\right.$, Fig. 1), in agreement with the flux calculated from the chloride mass balance.

Theoretical calculations of water evaporation potential from the vadose zone due to thermally driven convective air flow in the desiccation crack voids were performed using the equations described in Nachshon et al. (2008) and Weisbrod and Dragila (2006) (detailed descriptions of the equations are presented in the supporting information). Using the cracks' dimensions at the site (apertures of $0.003-0.05 \mathrm{~m}$; polygon size $1.0 \times 0.7 \mathrm{~m}^{2}$; depth $2 \mathrm{~m}$ ), the daily temperature gradients $\left(1-5^{\circ} \mathrm{C}\right)$ and the relative humidity $(\mathrm{RH})$ of the air in the atmosphere and in the cracks $(70 \%$ and $100 \%$, respectively) at the site, indicated high yearly evaporation potentials of $0.644-14900 \mathrm{~m} \mathrm{yr}^{-1}$. These calculated values represent the maximal evaporation potentials for a crack with two parallel walls when the temperature gradient prevails down to $2 \mathrm{~m}$ below the surface. The calculated values indicate an evaporation potential that is up to four orders of magnitude greater than the yearly infiltration. It is likely that just like with fractures in chalk, the loss of water from the cracked clayey subsurface is limited by (1) water transport through the clay sediment matrix to the crack surfaces, and (2) the water vapor concentration of the atmosphere (relative humidity) during the nighttime (Weisbrod and Dragila, 2006; Kamai et al., 2009). Accordingly, the slow matrix flow in the clay sediment and nights with high relative humidity probably limit the evaporation from the subsurface, such that only

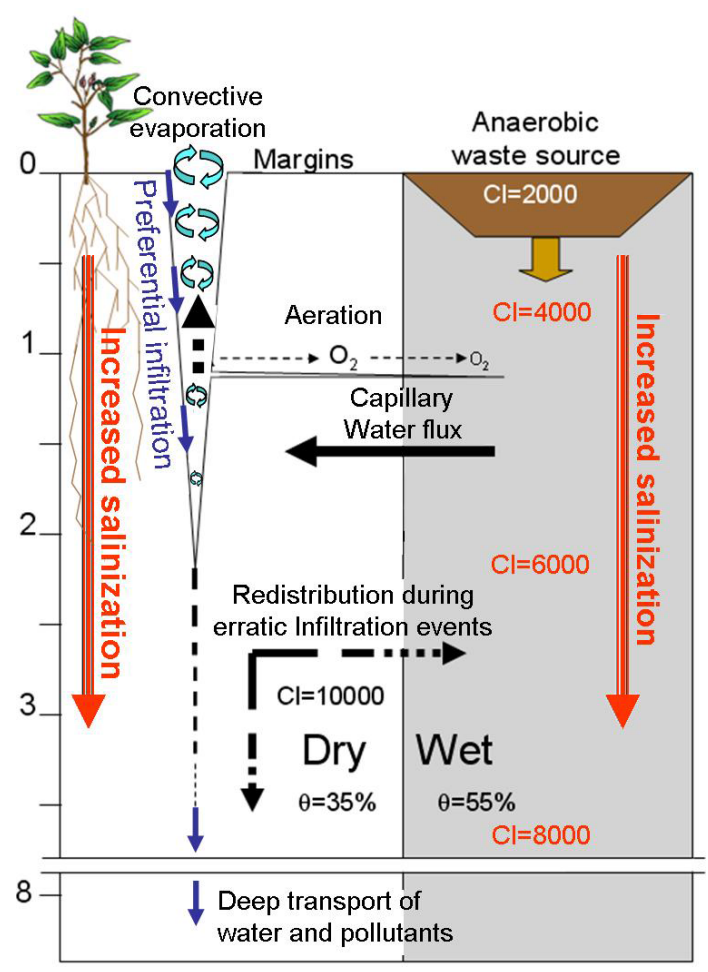

Fig. 8. Desiccation-crack-induced-salinization (DCIS) conceptual model.

a major fraction (85\%) of the propagating pore water evaporates from the upper $4 \mathrm{~m}$ of the vadose zone at the study site. The depth to which thermally driven evaporation can occur in conical-shaped fractures, like desiccation cracks, is still unknown and warrants further research.

Evaporation from a water body may be estimated through the relationship between the initial isotopic values of the water source and the isotopic values of the same water body following evaporation using the Rayleigh distillation equation. However, in order to properly estimate the evaporation based on Rayleigh's distillation equation, no water can be added to the system throughout the evaporation process. In this site, we know that this assumption is not valid since: (a) preferential infiltration of depleted rainwater reaches the subsurface and decreases the enriched evaporated values of the ambient water and (b) the subsurface values represent a mixture between the ambient enriched water (from the end of the summer) and the preferentially infiltrating water.

\section{Conclusions}

Our observations on increased salinization and isotopic enrichment to depths exceeding $4 \mathrm{~m}$ in a clay formation where infiltration is predominantly controlled by preferential flow in desiccation cracks shows that thermally driven evaporation in the deep sections of the vadose zone is a likely mechanism. 
Furthermore, this work expands on previous studies that have explored evaporation from cracked soil (Adams and Hanks, 1964; Adams et al., 1969; Selim and Kirkham, 1970; Ritchie and Adams, 1974) and provides comprehensive subsurface observations and a theoretical framework to explain why the presence of desiccation cracks increases the total evaporation from clay sediment and consequent sediment salinization. Combining observations on (1) rapid and deep water infiltration through desiccation cracks in clay sediments (Baram et al., 2012a), (2) increased sediment salinization with depth under the waste sources and their margins, (3) isotopic signature $\left(\delta^{2} \mathrm{H}\right.$ and $\left.\delta^{18} \mathrm{O}\right)$ of the vadose zone pore water that indicates subsurface evaporation, (4) transport of sorptive contaminants to deep sections of the vadose zone (Arnon et al., 2008), and (5) extensive aeration of the vadose zone, which supports nitrification under anaerobic water sources with a very high organic load (Baram et al., 2012b; Sher et al., 2012), has led to the development of a conceptual model, hereafter termed as desiccation-crack-induced salinization (DCIS) (Fig. 8).

The DCIS conceptual model suggests that thermally driven convective air flow in the desiccation cracks induces water evaporation in relatively deep sections of the subsurface (Fig. 8). Under these conditions, capillary flow between the wet sediment $\left(0.40-0.60 \mathrm{~m}^{3} \mathrm{~m}^{-3}\right)$ (high hydraulic potential) under the waste sources and the drier sediment $(0.25-$ $0.40 \mathrm{~m}^{3} \mathrm{~m}^{-3}$ ) (low hydraulic potential) under their margins is likely to be maintained, allowing continuous water vapor flux from the desiccation crack network to the surface (Fig. 8). As a result, high solute concentrations are built up in the deep sediment surrounding the crack network. Erratic preferential infiltration events that follow intensive rains and occasional flooding by waste of the waste source banks and margins transport solutes from the saline sediments surrounding the cracked zone, both vertically and laterally into the clayey cross section. These flushing events promote a gradual increase with depth of the solute concentration under the waste source and its margins.

The DCIS conceptual model was based on a set of systematic field observations presenting a complex relationship between gas flow, water flow and solute transport in an unsaturated clay vadose zone. Assessing the DCIS characteristics requires further work on simulations that would account for the (1) water flow and solute transport in clay sediment where the desiccation cracks' geometry, as well as the hydraulic properties of the clay matrix, changes dynamically; (2) the depth and rate to which water losses as vapor flux from desiccation cracks due to thermally driven evaporation can occur; and (3) solute accumulation and redistribution in a flow domain that is controlled by multiple flow mechanisms, such as preferential and matrix flow, as well as multiple flow directions and water sources. The DCIS conceptual model supports previous conceptual models on vadose zone and groundwater salinization in fractured rock in an arid environment (Weisbrod and Dragila, 2006) and extends its validity to clayey soils in semi-arid environments. The long-term pervasiveness of the suggested invading atmospheric plumes and their repeatability from winter to winter may have significant implications for the physical and chemical evolution of fractured vadose zones and need to be further explored.

\section{Supplementary material related to this article is available online at: http://www.hydrol-earth-syst-sci.net/ 17/1533/2013/hess-17-1533-2013-supplement.pdf.}

Acknowledgements. We thank Michael Kogel for his extensive efforts in the construction and operation of the VMS, the dairy farm owner for allowing us to conduct this research on his farm, Irena Pankratov for her lab work and Ms. Sara Elchanani for fruitful discussions. We express special gratitude to Noam Weisbrod for his helpful suggestions and constructive comments. The work was funded by Israel's Water Authority and by the Israel Science Foundation (Grant \# 141412). Comments and suggestions provided by M. Dragila, I. Jolly and an anonymous reviewer helped to significantly improve this manuscript.

Edited by: T. Blume

\section{References}

Acworth, R. I. and Timms, W. A.: Evidence for connected water processes through smectite-dominated clays at Breeza, New South Wales, Aust. J. Earth Sci., 56, 81-96, doi:10.1080/08120090802541952, 2009.

Adams, J. E. and Hanks, S.: Evaporation from soil shrinkage cracks, Soil Sci. Soc. Am. Pro., 28, 281-284, 1964.

Adams, J. E., Ritchie, J. T., Burnett, E., and Fryrear, D. W.: Evaporation from a simulated soil shrinkage crack, Soil Sci. Soc. Am. Pro., 33, 609-613, 1969.

Allison, G. B., Barnes, C. J., and Hughes, M. W.: The distribution of deuterium and ${ }^{18} \mathrm{O}$ in dry soils 2. Experimental, J. Hydrol., 64, 377-397, 1983.

Allison, G. B., Stone, W. J., and Hughes, M. W.: Recharge in karst and dune elements of a semi-arid landscape as indicated by natural isotopes and chloride, J. Hydrol., 76, 1-25, 1985.

Arnon, S., Dahan, O., Elhanany, S., Cohen, K., Pankratov, I., Gross, A., Ronen, Z., Baram, S., and Shore, L. S.: Transport of testosterone and estrogen from dairy-farm waste lagoons to groundwater, Environ. Sci. Technol., 42, 5521-5526, doi:10.1021/es800784m, 2008.

Asaf, L., Nativ, R., Shain, D., Hassan, M., and Geyer, S.: Controls on the chemical and isotopic compositions of urban stormwater in a semiarid zone, J. Hydrol., 294, 270-293, 2004.

Baram, S., Kurtzman, D., and Dahan, O.: Water percolation through a clayey vadose zone, J. Hydrol., 424-425, 165-171, 2012a.

Baram, S., Arnon, S., Ronen, Z., Kurtzman, D., and Dahan, O.: Infiltration mechanism controls nitrification and denitrification processes under dairy waste lagoons, J. Environ. Qual., 5, 16231632, doi:10.2134/jeq2012.0015, 2012 b. 
Barnes, C. J. and Allison, G. B.: The distribution of deuterium and ${ }^{18} \mathrm{O}$ in dry soils: 1 . Theory, J. Hydrol., 60, 141-156, 1983.

Barnes, C. J. and Allison, G. B.: Tracing of water movement in the unsaturated zone using stable isotopes of hydrogen and oxygen, J. Hydrol., 100, 143-176, 1988.

Bronswijk, J. J. B., Hamminga, W., and Oostindie, K.: Field-scale solute transport in a heavy clay soil, Water Resour. Res., 31, 517526, doi:10.1029/94WR02534, 1995.

Cook, P.G., Walker, G.R. and Jolly, I.D.: Spatial variability of groundwater recharge in a semiarid region, J. Hydrol., 111, 195212, 1989.

Costa, S., Kodikara, J., and Shannon, B.: Salient factors controlling desiccation cracking of clay in laboratory experiments, Geotechnique, 63, 18-29, 2013.

Dahan, O., Nativ, R., Adar, E. M., Berkowitz, B., and Ronen, Z.: Field observation of flow in a fracture intersecting unsaturated chalk, Water Resour. Res., 35, 3315-3326, 1999.

Dahan, O., Nativ, R., Adar, E. M., Berkowitz, B., and Weisbrod, N.: On fracture structure and preferential flow in unsaturated chalk, Ground Water, 38, 444-451, 2000.

Dahan, O., Shani, Y., Enzel, Y., Yechieli, Y., and Yakirevich, A.: Direct measurements of floodwater infiltration into shallow alluvial aquifers, J. Hydrol., 344, 157-170, 2007.

Dahan, O., Tatarsky, B., Enzel, Y., Kulls, C., Seely, M., and Benito, G.: Dynamics of flood water infiltration and ground water recharge in hyperarid desert, Ground Water, 46, 450-461, 2008.

Dahan, O., Talby, R., Yechieli, Y., Adar, E., Lazarovitch, N., and Enzel, Y.: In situ monitoring of water percolation and solute transport using a vadose zone monitoring system, Vadose Zone J., 8, 916-925, 2009.

Dawson, T. E. and Ehleringer, J. R.: Streamside trees that do not use stream water, Nature, 350, 335-337, 1991.

DePaolo, D. J., Conrad, M. E., Maher, K., and Gee, G. W.: Evaporation effects on oxygen and hydrogen isotopes in deep vadose zone pore fluids at Hanford, Washington, Vadose Zone J., 3, 220 232, 2004.

Fontes, J. C., Yousfi, M., and Allison, G. B.: Estimation of longterm, diffuse groundwater discharge in the Northern Sahara using stable isotope profiles in soil-water, J. Hydrol., 86, 315-327, 1986.

Gardner, W. R.: Water uptake and salt distribution pattern in saline soils, in: Isotopes and Radiation Techniques in Soil Physics and Irrigation Studies, Istanbul. Int., Energy Agency, Vienna, 335340, 1967.

Garvelmann, J., Külls, C., and Weiler, M.: A porewater-based stable isotope approach for the investigation of subsurface hydrological processes, Hydrol. Earth Syst. Sci., 16, 631-640, doi:10.5194/hess-16-631-2012, 2012.

Gazis, C. and Feng, X.: A stable isotope study of soil water: evidence for mixing and preferential flow paths, Geoderma, 119, 97-111, 2004.

Gerardi, M. H.: The Microbiology of Anaerobic Digesters, Hoboken, New Jersey, John Wiley \& Sons, Inc., 2003.

Gerke, H. H.: Preferential flow descriptions for structured soils, J. Plant Nutr. Soil Sci., 169, 382-400, 2006.

Greve, A., Andersen, M. S., and Acworth, R. I.: Investigations of soil cracking and preferential flow in a weighing lysimeter filled with cracking clay soil, J. Hydrol., 393, 105-113, 2010.
Ireson, A. M., Mathias, S. A., Wheater, H. S., Butler, A. P., and Finch, J.: A model for flow in the chalk unsaturated zone incorporating progressive weathering, J. Hydrol., 365, 244-260, 2009.

Issar, A.: Geology of Central Coastal Plain of Israel, Israel J. Earth Sci., 17, 16-29, 1968.

Kamai, T., Weisbrod, N., and Dragila, M. I.: Impact of ambient temperature on evaporation from surface-exposed fractures, Water Resour. Res., 45, W02417, doi:10.1029/2008WR007354, 2009.

Kishne, A. S., Morgan, C. L. S., Ge, Y. F., and Miller, W. L.: Antecedent soil moisture affecting surface cracking of a Vertisol in field conditions, Geoderma, 157, 109-117, 2010.

Kurtzman, D. and Scanlon, B. R.: Groundwater recharge through Vertisols - irrigated cropland versus natural land, Israel, Vadose Zone J., 10, 662-674, 2011.

Landon, M. K., Delin, G. N., Komor, S. C., and Regan, C. P.: Comparison of the stable-isotopic composition of soil water collected from suction lysimeters, wick samplers, and cores in a sandy unsaturated zone, J. Hydrol., 224, 45-54, 1999.

Mermut, A. R., Dasog, G. S., and Dowuona, G. N.: Soil morphology, in: Vertisols and technologies for their management, edited by: Ahmed, N. and Mermut, A., Amsterdam: Elsevier Science, 89-110, 1996.

Nachshon, U., Weisbrod, N., and Dragila, M. I.: Quantifying air convection through surface-exposed fractures: A laboratory study, Vadose Zone J., 7, 948-956, 2008.

Nachshon, U., Dragila, M., and Weisbrod, N.: From atmospheric winds to fracture ventilation: Cause and effect, J. Geophys. Res.Biogeosci., 117, G02016, doi:10.1029/2011JG001898, 2012.

Nahlawi, H. and Kodikara, J.: Laboratory experiments on desiccation cracking of thin soil layers, Geotech. Geol. Eng., 24, 16411664, 2006.

Nativ, R., Adar, E., Dahan, O., and Geyh, M.: Water recharge and solute transport through the vadose zone of fractured chalk under desert conditions, Water Resour. Res., 31, 253-261, 1995.

Nativ, R., Adar, E., Dahan, O., and Nissim, I.: Water salinization in arid regions - observations from the Negev desert, Israel, J. Hydrol., 196, 271-296, 1997.

Radford, B. J., Silburn, D. M., and Forster, B. A.: Soil chloride and deep drainage responses to land clearing for cropping at seven sites in central Queensland, northern Australia, J. Hydrol., 379, 20-29, 2009.

Rimon, Y., Dahan, O., Nativ, R., and Geyer, S.: Water percolation through the deep vadose zone and groundwater recharg: preliminary results based on a new vadose-zone monitoring system, Water Resour. Res., 43, W05402, doi:10.1029/2006WR004855, 2007.

Rimon, Y., Nativ, R., and Dahan, O.: Physical and chemical evidence for pore-scale dual-domain flow in the vadose zone, Vadose Zone J., 10, 322-331, 2011.

Ritchie, J. T. and Adams, J. E.: Field measurement of evaporation from soil shrinkage cracks, Soil Sci. Soc. Am. Pro., 38, 131-134, 1974.

Scanlon, B. R.: Evaluation of moisture flux from chloride data in desert soils, J. Hydrol., 128, 137-156, 1991.

Scanlon, B. R. and Goldsmith, R. S.: Field study of spatial variability in unsaturated flow beneath and adjacent to playas, Water Resour. Res., 33, 2239-2252, 1997.

Scanlon, B. R., Tyler, S., and Wierenga, P.: Hydrologic issues in arid, unsaturated systems and implications for contaminant trans- 
port, Rev. Geophys., 35, 461-490, 1997.

Scanlon, B. R., Jolly, I., Sophocleous, M., and Zhang, L.: Global impacts of conversions from natural to agricultural ecosystems on water resources: Quantity versus quality, Water Resour. Res., 43, W03437. doi:10.1029/2006WR005486, 2007.

Selim, H. M. and Kirkham, D.: Soil temperature and water content changes during drying as influenced by cracks: A laboratory experiment, Soil Sci. Soc. Am. Pro., 34, 565-569, 1970.

Sharma, M. L. and Hughes, M. W.: Groundwater recharge estimation using chloride, deuterium and oxygen-18 profiles in the deep coastal sands of Western Australia, J. Hydrol., 81, 93-109, 1985.

Sher, Y., Baram, S., Dahan, O., Ronen, Z., and Nejidat, A.: Nitrogen transformations and abundance of nitrifiers and denitrifiers in a clay soil underlying a manure pond, FEMS Microbiol. Ecol., 81, 145-155, 2012.

Simunek, J., Sejna, M., and van Genuchten, M. T.: The HYDRUS1D software package for simulating the one-dimensional movement of water, heat, and multiple solutes in variably saturated media, in: IGWMC-TPS-70, Golden, CO: International Groundwater Modeling Center: Colorado School of Mines, 1998.

Thorburn, P. J., Walker, G. R., and Brunel, J. P.: Extraction of water from Eucalyptus trees for analysis of deuterium and O-18 - Laboratory and field techniques, Plant Cell Environ., 16, 269-277, 1993.
Weinberger, G.: The development and use of water resources in Israel until autumn 2006, in: Jerusalem: Ministry of National Infrastructure, 405 pp., 2007 (in Hebrew).

Weisbrod, N. and Dragila, M. I.: Potential impact of convective fracture venting on salt-crust buildup and ground-water salinization in arid environments, J. Arid. Environ., 65, 386-399, 2006.

Weisbrod, N., Nativ, R., Adar, E. M., and Ronen, D.: Salt accumulation and flushing in unsaturated fractures in an arid environment, Ground Water, 38, 452-461, 2000.

Weisbrod, N., Dragila, M. I., Nachshon, U., and Pillersdorf, M.: Falling through the cracks: The role of fractures in Earthatmosphere gas exchange, Geophys. Res. Lett., 36, L02401, doi:10.1029/2008GL036096, 2009.

Zhou, Q. L., Salve, R., Liu, H. H., Wang, J. S. Y., and Hudson, D.: Analysis of a mesoscale infiltration and water seepage test in unsaturated fractured rock: Spatial variabilities and discrete fracture patterns, J. Contam. Hydrol., 87, 96-122, 2006. 